University of Nebraska - Lincoln

DigitalCommons@University of Nebraska - Lincoln

$1-1-2004$

\title{
Tillage and cropping effects on soil quality indicators in the northern Great Plains
}

\author{
Mark A. Liebig \\ USDA-ARS, mark.liebig@ars.usda.gov \\ D. L. Tanaka \\ USDA-ARS, Don.Tanaka@ars.usda.gov \\ Brian J. Wienhold \\ University of Nebraska-Lincoln, Brian.Wienhold@ars.usda.gov
}

Follow this and additional works at: https://digitalcommons.unl.edu/usdaarsfacpub

Part of the Agricultural Science Commons

Liebig, Mark A.; Tanaka, D. L.; and Wienhold, Brian J., "Tillage and cropping effects on soil quality indicators in the northern Great Plains" (2004). Publications from USDA-ARS / UNL Faculty. 207. https://digitalcommons.unl.edu/usdaarsfacpub/207

This Article is brought to you for free and open access by the U.S. Department of Agriculture: Agricultural Research Service, Lincoln, Nebraska at DigitalCommons@University of Nebraska - Lincoln. It has been accepted for inclusion in Publications from USDA-ARS / UNL Faculty by an authorized administrator of DigitalCommons@University of Nebraska - Lincoln. 


\title{
Tillage and cropping effects on soil quality indicators in the northern Great Plains
}

\author{
M.A. Liebig ${ }^{\mathrm{a}, *}$, D.L. Tanaka ${ }^{\mathrm{a}}$, B.J. Wienhold ${ }^{\mathrm{b}}$ \\ ${ }^{a}$ USDA-ARS, Northern Great Plains Research Laboratory, P.O. Box 459, Mandan, ND 58554, USA \\ ${ }^{\mathrm{b}}$ USDA-ARS, Soil and Water Conservation Research Unit, 120 Keim Hall, Department of Agronomy, \\ University of Nebraska, Lincoln, NE 68583, USA
}

\begin{abstract}
The extreme climate of the northern Great Plains of North America requires cropping systems to possess a resilient soil resource in order to be sustainable. This paper summarizes the interactive effects of tillage, crop sequence, and cropping intensity on soil quality indicators for two long-term cropping system experiments in the northern Great Plains. The experiments, located in central North Dakota, were established in 1984 and 1993 on a Wilton silt loam (FAO: Calcic Siltic Chernozem; USDA $^{1}$ : fine-silty, mixed, superactive frigid Pachic Haplustoll). Soil physical, chemical, and biological properties considered as indicators of soil quality were evaluated in spring 2001 in both experiments at depths of $0-7.5,7.5-15$, and $15-30 \mathrm{~cm}$. Management effects on soil properties were largely limited to the surface $7.5 \mathrm{~cm}$ in both experiments. For the experiment established in 1984, differences in soil condition between a continuous crop, no-till system and a crop-fallow, conventional tillage system were substantial. Within the surface $7.5 \mathrm{~cm}$, the continuous crop, no-till system possessed significantly more soil organic C (by $7.28 \mathrm{Mg} \mathrm{ha}^{-1}$ ), particulate organic matter C (POM-C) (by $4.98 \mathrm{Mg} \mathrm{ha}^{-1}$ ), potentially mineralizable $\mathrm{N}$ (PMN) (by $32.4 \mathrm{~kg} \mathrm{ha}^{-1}$ ), and microbial biomass $\mathrm{C}$ (by $586 \mathrm{~kg} \mathrm{ha}^{-1}$ ), as well as greater aggregate stability (by $33.4 \%$ ) and faster infiltration rates (by $55.6 \mathrm{~cm} \mathrm{~h}^{-1}$ ) relative to the crop-fallow, conventional tillage system. Thus, soil from the continuous crop, no-till system was improved with respect to its ability to provide a source for plant nutrients, withstand erosion, and facilitate water transfer. Soil properties were affected less by management practices in the experiment established in 1993, although organic matter related properties tended to be greater under continuous cropping or minimum tillage than crop sequences with fallow or no-till. In particular, PMN and microbial biomass $\mathrm{C}$ were greatest in continuous spring wheat (with residue removed) (22.5 $\mathrm{kg} \mathrm{ha}^{-1}$ for PMN; $792 \mathrm{~kg} \mathrm{ha}^{-1}$ for microbial biomass C) as compared with sequences with fallow (SW-S-F and SW-F) (Average $=15.9 \mathrm{~kg} \mathrm{ha}^{-1}$ for PMN; $577 \mathrm{~kg} \mathrm{ha}^{-1}$ for microbial biomass C). Results from both experiments confirm that farmers in the northern Great Plains of North America can improve soil quality and agricultural sustainability by adopting production systems that employ intensive cropping practices with reduced tillage management.
\end{abstract}

(C) 2004 Elsevier B.V. All rights reserved.

Keywords: No-till; Continuous cropping; Soil quality; Wilton silt loam; Northern Great Plains

\footnotetext{
* Corresponding author. Tel.: +1-701-667-3079; fax: +1-701-667-3054.

E-mail address: liebigm@mandan.ars.usda.gov (M.A. Liebig).

1 The US Department of Agriculture, Agricultural Research Service is an equal opportunity/affirmative action employer and all agency services are available without discrimination.
}

\section{Introduction}

The northern Great Plains of North America is recognized throughout the world for its fertile soils, which contribute to the production of large quantities of cereal grain and oilseed crops. This area, which includes much of Montana, North Dakota, South 
Dakota, and Wyoming in the United States as well as the Prairie Provinces of Canada, contributes over US\$ 20 billion in annual agricultural output (Statistics Canada, 1996; US Census Bureau, 2000). However, the northern Great Plains is also known for its extreme climate. Droughts, wet-periods, intense precipitation events, and extreme temperatures are commonplace, and have contributed to the historic boom-and-bust economic cycles that are a trademark of the region (Peterson, 1996).

The region's unpredictable climate has challenged agriculturists since the arrival of European settlers over 130 years ago. Farming practices in the region have evolved from tillage-dependent wheat (Triticum aestivum L.)-fallow systems to continuous cropping practices under no-till management (Peterson, 1996). The advancement of farming practices has placed greater emphasis on the retention of plant residues on the soil surface, thereby mimicking native ecosystems.

Changes in soil condition due to surface residue accumulation in continuous crop, no-till systems are substantial and are characterized by increased soil organic matter (Bowman et al., 1999; Campbell et al., 1996, 1997; Halvorson et al., 2002), improvements in soil physical properties (Arshad et al., 1999; Pikul and Aase, 1995), enhanced microbial activity and biomass (Doran, 1980; Salinas-Garcia et al., 1997; Staley et al., 1988), decreased soil pH (Bowman and Halvorson, 1998; Dick, 1983), and increased surface concentration of nutrients available to plants (Follett and Peterson, 1988; Tracy et al., 1990). These changes in soil condition have improved the functioning of cropping systems in the northern Great Plains by increasing water storage (Deibert et al., 1986; Tanaka and Anderson, 1997; Peterson et al., 1996), reducing soil erosion (Merrill et al., 1999), and enhancing mineral N conservation (Follett and Schimel, 1989).

While advances in management have been made in the northern Great Plains to enhance cropping system performance through improvements in soil condition, research is needed to better understand the interactions of tillage, crop sequence, and cropping intensity on the broad spectrum of physical, chemical, and biological soil properties considered to be indicators of soil quality. Understanding management effects on near-surface properties, in particular, is vitally important given the impact the soil surface has on erosion control, water infiltration, and nutrient conservation (Franzluebbers, 2002).

This paper summarizes the interactive effects of tillage, crop sequence, and cropping intensity on soil properties, with particular focus on properties considered as soil quality indicators. Data were used from two long-term cropping system experiments conducted in central North Dakota. The guiding hypothesis for the work was that improvements in soil quality (as reflected by changes in soil physical, chemical, and biological properties) would occur under management systems employing continuous cropping or reduced tillage.

\section{Materials and methods}

The long-term cropping system experiments were located approximately $6 \mathrm{~km}$ southwest of Mandan, ND in Morton County $\left(46^{\circ} 46^{\prime} 22^{\prime \prime} \mathrm{N}, 100^{\circ} 57^{\prime} 09^{\prime \prime} \mathrm{W}\right)$. The site is on gently rolling uplands (0-3\% slope) with a silty loess mantle overlying till. The predominant soil at the site is a Wilton silt loam. From 1914 to 2000, annual precipitation has averaged $409 \mathrm{~mm}$, with $79 \%$ of the total received during the growing season from April to September. Average annual temperature is $4{ }^{\circ} \mathrm{C}$, though daily averages range from $21^{\circ} \mathrm{C}$ in the summer to $-11^{\circ} \mathrm{C}$ in the winter.

\subsection{Description of experiments}

The first long-term cropping system experiment was established in 1984. Management variables included in the experiment were crop sequence (spring wheat ( $T$. aestivum $\mathrm{L}$.)-fallow (SW-F) and spring wheat-winter wheat (T. aestivum L.)-sunflower (Helianthus annuus $\mathrm{L}$.) (SW-WW-SF)), tillage (conventional tillage (CT), minimum tillage (MT), and no-till (NT)), and $\mathrm{N}$ fertilization $\left(0,22\right.$, and $45 \mathrm{~kg} \mathrm{Nha}^{-1}$ for $\mathrm{SW}-\mathrm{F}$ and 34, 67, and $101 \mathrm{~kg} \mathrm{Nha}^{-1}$ for SW-WW-SF). Each phase of both crop sequences was present every year. Conventional tillage involved use of a tandem disk and chisel plow in the fall and spring to control weeds, incorporate crop residue, and prepare the seedbed. The disk possessed $46 \mathrm{~cm}$ blades, which were spaced apart by $22 \mathrm{~cm}$. The chisel plow had $18 \mathrm{~cm}$ blades attached to curved spikes, which were separated by a distance of $18 \mathrm{~cm}$. Minimum tillage utilized one or 
two tillage passes with a sweep plow in the fall and spring. Blade width and shank spacing for the sweep plow was $66 \mathrm{~cm}$. In NT, the soil surface was not disturbed except at planting. In the SW-F sequence, plots were generally not tilled in the fall following SW harvest. Maximum depth of soil disturbance by tillage was approximately $15 \mathrm{~cm}$ in CT and $8 \mathrm{~cm}$ in MT. Crop residue covered $<30 \%$ of the soil surface under CT, 30-60\% under MT, and $>60 \%$ under NT. Burn-down and post-emergent herbicides were applied in all tillage treatments to control weeds as needed. Nitrogen was applied as a broadcast application of $\mathrm{NH}_{4} \mathrm{NO}_{3}$ in the spring of each crop year prior to tillage. The experimental design was a strip-split plot with tillage and $\mathrm{N}$ fertilization treatments stripped with three replications (Halvorson et al., 2002). The experiment occupied approximately 26 ha with individual plots $24.4 \mathrm{~m} \times 45.7 \mathrm{~m}$ in size, thereby allowing use of field-scale equipment for all operations.

The second long-term cropping system experiment was established in 1993. Management variables in the experiment were crop sequence (continuous spring wheat with crop residue left on the soil surface $(\mathrm{CSW}+)$, continuous spring wheat with crop residue removed $(\mathrm{CSW}-)$, spring wheat-millet (Setaria italica (L.) Beauv.) (SW-M), spring wheat-safflower (Carthamus tinctorius L.)-fallow (SW-S-F), spring wheat-safflower-rye (Secale cereale L.) (SW-S-R), and spring wheat-fallow (SW-F)) and tillage (minimum tillage (MT) and no-till (NT)). Each phase of all crop sequences was present every year. Minimum tillage and NT treatments were employed as described above. Fertilization was conducted in the spring by broadcast applying $67 \mathrm{~kg} \mathrm{Nha}^{-1}$ (as $\mathrm{NH}_{4} \mathrm{NO}_{3}$ ) after a crop and $34 \mathrm{~kg} \mathrm{Nha}^{-1}$ after fallow. Triple superphosphate was applied at $11 \mathrm{~kg} \mathrm{Pha}^{-1}$ with the seed at planting. The experimental design was a split-plot, with crop sequences as whole plots and tillage as subplots. Treatment combinations were replicated three times. Individual plots were $9.1 \mathrm{~m} \times 30.1 \mathrm{~m}$ in size.

\subsection{Sampling protocol}

Soil samples were collected in the spring of 2001 prior to tillage operations in both experiments. For the 1984 experiment, samples were collected from contrasting treatments ((SW-WW-SF, NT, $67 \mathrm{~kg} \mathrm{~N} \mathrm{ha}^{-1}$ ) and (SW-F, CT, $\left.22 \mathrm{~kg} \mathrm{Nha}^{-1}\right)$ ). Sampling was con- ducted in the fallow phase of the SW-F sequence, and in the winter wheat phase of the SW-WW-SF sequence. As a contrast to the treatments in the 1984 experiment, samples were collected in three pseudo-plots from a nearby moderately grazed pasture with the same soil type. The pasture had been grazed with 2.6 ha per steer for approximately 140 days per year since 1916. For the 1993 experiment, samples were collected in all plots cropped the previous year to spring wheat. Twelve soil cores were collected in each plot from three depths, 0-7.5, 7.5-15, and $15-30 \mathrm{~cm}$ using a $3.5 \mathrm{~cm}$ (i.d.) step-down probe and composited by depth. To ensure composite samples were representative of each plot, four cores each were collected from the row, wheel tracked interrow, and non-wheel tracked interrow. Each sample was saved in a double-lined plastic bag, placed in cold storage at $5{ }^{\circ} \mathrm{C}$, and analyzed for chemical and biological attributes within 2 weeks of collection.

\subsection{Laboratory evaluations}

Samples were processed by sieving through a $2.0 \mathrm{~mm}$ sieve at field moisture content and subsampled for chemical and biological analyses. Electrical conductivity (EC) and soil $\mathrm{pH}$ were estimated from a 1:1 soil-water mixture (Dahnke and Whitney, 1988; Eckert, 1988). Soil $\mathrm{NO}_{3}-\mathrm{N}$ and $\mathrm{NH}_{4}-\mathrm{N}$ were estimated from 1:10 soil- $\mathrm{KCl}(2 \mathrm{M})$ extracts using cadmium reduction followed by a modified Griess-Ilosvay method and indophenol blue reaction (Mulvaney, 1996). Total C and N were determined by dry combustion. Organic $\mathrm{C}$ was considered the same as total $\mathrm{C}$ as carbonates were not present in the depths sampled. Particulate organic matter (POM) was estimated two ways. For the 1984 experiment and grazed pasture, material retained on a $0.053 \mathrm{~mm}$ sieve was collected and evaluated for $\mathrm{C}$ and $\mathrm{N}$ content (Gregorich and Ellert, 1993). For the 1993 experiment, POM was estimated by weight loss-on-ignition for the $0.053-0.5$ and $0.5-2.0 \mathrm{~mm}$ size fractions (Cambardella et al., 2000). Evaluations of total C and N and POM-C and -N were conducted on air-dried material ground with a roller mill to pass a 100 -mesh sieve.

Potentially mineralizable N (PMN) was estimated from the $\mathrm{NH}_{4}-\mathrm{N}$ accumulated after a 7 day anaerobic incubation at $40^{\circ} \mathrm{C}$ (Bundy and Meisinger, 1994). Soil microbial biomass $\mathrm{C}$ was estimated using the 
microwave irradiation technique (Islam and Weil, 1998). Fifty grams of field moist soil was incubated 10 days at $55 \%$ water-filled pore space in the presence of $10 \mathrm{ml}$ of $2.0 \mathrm{M} \mathrm{NaOH}$. Carbon dioxide content was determined by single end-point titration with $0.1 \mathrm{M}$ $\mathrm{HCl}$ (Paul et al., 1999). Flush of $\mathrm{CO}_{2}-\mathrm{C}$ following irradiation was calculated without subtraction of a 10 day control as suggested by Franzluebbers et al. (1999). Soil microbial biomass $\mathrm{N}$ was estimated from a 10 day mineral $\mathrm{N}$ flush between irradiated and non-irradiated soil following the method of Shen et al. (1984).

Gravimetric data were converted to a volumetric basis by sampling depth using field measured soil bulk density (Blake and Hartge, 1986). Wet aggregate stability of the $1-2 \mathrm{~mm}$ fraction was determined on replicate $4 \mathrm{~g}$ samples for treatments in the 1984 experiment following the method of Kemper and Rosenau (1986). All data were expressed on an oven-dry basis. In addition to laboratory assessments, infiltration rate was measured with single-ring infiltrometers at the time of sampling in the 1984 experiment and moderately grazed pasture (Sarrantonio et al., 1996).

\subsection{Statistical analysis}

Treatment effects on soil properties were evaluated using appropriate models in PROC MIXED (Littell et al., 1996). For the 1993 experiment, replication and its interaction with crop sequence were considered random effects. Because the experiments had been conducted for different lengths of time, treatment means were compared using least significant differences (LSD) at $P<0.05$ for the 1984 experiment, and at $P<0.1$ for the 1993 experiment. Correlation analysis was used to identify relationships between stover yield and soil properties from 0 to $7.5 \mathrm{~cm}$ depth in the 1993 experiment. Data for stover yield represented total stover production from 1993 to 2000 in the same plots where soil samples were collected. Significant correlations were identified using PROC REG (SAS Institute, 1990).

\section{Results and discussion}

Management effects on soil properties were largely limited to the surface $7.5 \mathrm{~cm}$ in both experiments (Tables 1 and 2). Eleven of 15 indicators were significantly affected $(P<0.05)$ by cropping system at $0-7.5 \mathrm{~cm}$ in the 1984 experiment, with only 4 of 11 indicators affected below that depth (Table 1). For the 1993 experiment, 7 of 13 indicators were affected $(P<0.1)$ by crop sequence and tillage each at $0-7.5 \mathrm{~cm}$ (Table 2). Below $7.5 \mathrm{~cm}$, only EC and soil bulk density were affected by crop sequence and tillage, respectively $(7.5-15 \mathrm{~cm}$ depth only; data

Table 1

Summary of $P$-values from analysis of variance showing the effect of cropping system on soil properties at $0-7.5,7.5-15$, and $15-30 \mathrm{~cm}$ for a long-term cropping systems experiment established in 1984 near Mandan, ND

\begin{tabular}{llll}
\hline Soil property & \multicolumn{2}{l}{ Soil depth } & \\
\cline { 2 - 4 } & $0-7.5 \mathrm{~cm}$ & $7.5-15 \mathrm{~cm}$ & 0.2391 \\
\hline Soil bulk density & 0.3797 & - & 0.3739 \\
Wet aggregate stability, 1-2 mm fraction & 0.0050 & - & - \\
Infiltration rate & 0.0474 & 0.9891 & - \\
Electrical conductivity & 0.0643 & 0.6940 & 0.0463 \\
Soil pH & 0.2128 & 0.3701 & 0.3589 \\
Soil nitrate & 0.2599 & 0.1603 & 0.0151 \\
Soil organic C & 0.0165 & 0.0654 & 0.2125 \\
Total soil N & 0.0051 & 0.0588 & 0.1985 \\
Particulate organic matter-C & 0.0006 & 0.0973 & 0.3522 \\
Particulate organic matter-N & 0.0007 & 0.0724 & 0.4145 \\
Percentage of POM-C as soil organic C & 0.0003 & 0.1643 & 0.8729 \\
Percentage of POM-N as total soil N & 0.0005 & 0.0125 & 0.9921 \\
Potentially mineralizable N & 0.0075 & - & -0.0298 \\
Microbial biomass C & 0.0234 & - & - \\
Microbial biomass N & 0.0003 & & \\
\hline
\end{tabular}


Table 2

Summary of $P$-values from analysis of variance showing main and interactive effects of tillage and crop sequence on soil properties at 0-7.5 cm for a long-term cropping systems experiment established in 1993 near Mandan, ND

\begin{tabular}{llcc}
\hline Soil property & \multicolumn{2}{l}{ Source of variation } & \\
\cline { 2 - 4 } & Tillage & Sequence & Tillage $\times$ sequence \\
\hline Soil bulk density & 0.0805 & 0.5905 & 0.8097 \\
Electrical conductivity & 0.7820 & 0.4342 & 0.5838 \\
Soil pH & 0.6615 & 0.0009 & 0.8803 \\
Soil nitrate & 0.8442 & 0.2055 & 0.3457 \\
Soil organic C & 0.4636 & 0.1724 & 0.8925 \\
Total soil N & 0.5854 & 0.1297 & 0.9612 \\
Particulate organic matter & & & 0.2588 \\
$\quad 0.053-0.5$ mm & 0.0581 & $<0.0001$ & 0.7219 \\
0.5-2.0 mm & 0.0725 & $<0.0001$ & 0.4819 \\
0.053-2.0 mm & 0.0352 & $<0.0001$ & 0.2091 \\
SOM (\%) & 0.0020 & $<0.0001$ & 0.7051 \\
Potentially mineralizable N & 0.0315 & 0.0941 & 0.2153 \\
Microbial biomass C & 0.0744 & 0.0984 & 0.8671 \\
Microbial biomass N & 0.3539 & 0.2169 &
\end{tabular}

not shown). Based on $P$-values, POM was the most sensitive indicator of management effects in both experiments.

\subsection{4 experiment}

Treatment effects on soil quality indicators in the 1984 experiment were consistent with previously published reports for cropping system impacts on soil properties in the Great Plains (Havlin et al., 1990; Aase and Pikul, 1995; Pikul and Aase, 1995; Campbell et al., 1996; Wienhold and Halvorson, 1998; Bowman et al., 1999; Gajda et al., 2000). Among soil physical properties, wet aggregate stability and infiltration rate were over three-fold greater in SW-WW-SF, NT as compared with SW-F, CT (Table 3). These observations are supported by Arshad et al. (1999), where long-term effects of NT in northwestern Canada were found to improve aggregate stability and water transmission in surface soil relative to CT. Treatment effects on soil chemical properties were limited to the $15-30 \mathrm{~cm}$ depth, with $\mathrm{EC}$ and soil $\mathrm{NO}_{3}-\mathrm{N}$ greater in SW-F, CT than SW-WW-SF, NT (Table 3). Across all depths, however, values for EC were non-saline, while soil $\mathrm{pH}$ values were within thresholds optimal for crop growth and soil microbial activity (Smith and Doran, 1996).
The SW-WW-SF, NT system enhanced all Cand $\mathrm{N}$-related properties relative to SW-F, CT. Soil organic $\mathrm{C}$ and total $\mathrm{N}$ were 7.28 and $0.61 \mathrm{Mg} \mathrm{ha}^{-1}$ greater, respectively, in SW-WW-SF, NT than SW-F, CT (Table 3). In the first 12 years of this experiment, Halvorson et al. (2002) found the continuous crop, NT system to sequester an average of $233 \mathrm{~kg} \mathrm{Cha}^{-1}$ per year. Using this value, approximately $3.96 \mathrm{Mg} \mathrm{Cha}^{-1}$ would have been sequestered in the SW-WW-SF, NT system from 1984 to 2001. Likewise in the same time period, approximately $3.32 \mathrm{MgCha}^{-1}$ would have been lost from SW-F, CT. Trends in POM-C and $-\mathrm{N}$ between treatments were similar to SOC and TN. Levels of this intermediately labile soil organic matter fraction were 4.98 and $0.33 \mathrm{Mg} \mathrm{ha}^{-1}$ greater for POM-C and $-\mathrm{N}$, respectively, in SW-WW-SF, NT than in SW-F, CT. Accordingly, percentages of POM-C and $-\mathrm{N}$ as SOC and TN were approximately two-fold greater in SW-WW-SF, NT as compared with SW-F, CT (Table 3).

Greater $\mathrm{N}$ mineralization potential over the growing season was evident in SW-WW-SF, NT as compared with SW-F, CT, as values for PMN were significantly higher for the former treatment at all three depths (Table 3). Actual $\mathrm{N}$ mineralization rates for the same treatments were found in a previous study to be over two-fold greater in SW-WW-SF, NT as compared 
Table 3

Effect of cropping system on soil properties for a long-term cropping system experiment established in 1984 near Mandan, ND

\begin{tabular}{|c|c|c|c|}
\hline Soil property & SW-F, CT & SW-WW-SF, NT & Grazed pasture ${ }^{\mathrm{b}}$ \\
\hline \multicolumn{4}{|l|}{$0-7.5 \mathrm{~cm}^{\mathrm{c}}$} \\
\hline Soil bulk density $\left(\mathrm{Mg} \mathrm{m}^{-3}\right)$ & 1.19 & 1.13 & 0.85 \\
\hline Wet aggregate stability, $1-2 \mathrm{~mm}$ fraction $(\%)$ & $13.9 \mathrm{~b}^{\mathrm{d}}$ & $47.3 \mathrm{a}$ & 92.8 \\
\hline Infiltration rate $\left(\mathrm{cm} \mathrm{h}^{-1}\right)$ & $20.3 \mathrm{~b}$ & $75.9 \mathrm{a}$ & 29.1 \\
\hline $\mathrm{EC}\left(\mathrm{dS} \mathrm{m}^{-1}\right)^{\mathrm{e}}$ & 0.14 & 0.19 & 0.26 \\
\hline Soil $\mathrm{pH}\left(-\log \left[\mathrm{H}^{+}\right]\right)$ & 6.43 & 6.16 & 6.27 \\
\hline Soil $\mathrm{NO}_{3}-\mathrm{N}\left(\mathrm{kg} \mathrm{ha}^{-1}\right)$ & 1.9 & 3.0 & 7.2 \\
\hline $\operatorname{SOC}\left(\mathrm{Mgha}^{-1}\right)$ & $16.42 \mathrm{~b}$ & $23.70 \mathrm{a}$ & 31.56 \\
\hline $\mathrm{TN}\left(\mathrm{Mg} \mathrm{ha}^{-1}\right)$ & $1.63 \mathrm{~b}$ & $2.24 \mathrm{a}$ & 2.55 \\
\hline POM-C $\left(\mathrm{Mg} \mathrm{ha}^{-1}\right)$ & $2.61 \mathrm{~b}$ & $7.59 \mathrm{a}$ & 15.77 \\
\hline POM-N $\left(\mathrm{Mg} \mathrm{ha}^{-1}\right)$ & $0.21 \mathrm{~b}$ & $0.54 \mathrm{a}$ & 1.04 \\
\hline $\mathrm{POM}-\mathrm{C}$ as $\mathrm{SOC}(\%)$ & $16.0 \mathrm{~b}$ & $32.0 \mathrm{a}$ & 50.1 \\
\hline $\mathrm{POM}-\mathrm{N}$ as $\mathrm{TN}(\%)$ & $12.8 \mathrm{~b}$ & $24.1 \mathrm{a}$ & 40.8 \\
\hline PMN $\left(\mathrm{kg} \mathrm{ha}^{-1}\right)$ & $24.1 \mathrm{~b}$ & $56.5 \mathrm{a}$ & 85.7 \\
\hline Microbial biomass $\mathrm{C}\left(\mathrm{kg} \mathrm{ha}^{-1}\right)$ & $424 \mathrm{~b}$ & $1010 \mathrm{a}$ & 1598 \\
\hline Microbial biomass $\mathrm{N}\left(\mathrm{kg} \mathrm{ha}^{-1}\right)$ & $39 \mathrm{~b}$ & $100 \mathrm{a}$ & 148 \\
\hline \multicolumn{4}{|l|}{$7.5-15 \mathrm{~cm}$} \\
\hline $\operatorname{PMN}\left(\mathrm{kg} \mathrm{ha}^{-1}\right)$ & $14.4 \mathrm{~b}$ & $25.6 \mathrm{a}$ & 41.6 \\
\hline \multicolumn{4}{|l|}{$15-30 \mathrm{~cm}$} \\
\hline $\mathrm{EC}\left(\mathrm{dS} \mathrm{m}^{-1}\right)$ & $0.26 \mathrm{a}$ & $0.19 \mathrm{~b}$ & 0.18 \\
\hline Soil $\mathrm{NO}_{3}-\mathrm{N}\left(\mathrm{kg} \mathrm{ha}^{-1}\right)$ & $7.7 \mathrm{a}$ & $3.8 \mathrm{~b}$ & 0.3 \\
\hline PMN $\left(\mathrm{kg} \mathrm{ha}^{-1}\right)$ & $11.7 \mathrm{~b}$ & $30.7 \mathrm{a}$ & 46.8 \\
\hline
\end{tabular}

${ }^{a}$ SW-F, CT: spring wheat-fallow, conventional tillage, $22 \mathrm{~kg} \mathrm{~N} \mathrm{ha}^{-1}$ per year; SW-WW-SF, NT: spring wheat-winter wheat-sunflower, no-tillage, $67 \mathrm{~kg} \mathrm{Nha}^{-1}$ per year.

${ }^{\mathrm{b}}$ As a contrast, soil properties within a grazed pasture with the same soil type are shown.

${ }^{\mathrm{c}}$ All properties are presented for $0-7.5 \mathrm{~cm}$. Below $7.5 \mathrm{~cm}$, only properties affected by cropping system are shown.

${ }^{\mathrm{d}}$ Values for cropping system within a row followed by a different letter are significantly different at $P<0.05$.

${ }^{\mathrm{e}} \mathrm{EC}$ : electrical conductivity; SOC: soil organic carbon; TN: total nitrogen; POM: particulate organic matter; PMN: potentially mineralizable $\mathrm{N}$.

with SW-F, CT for the 0-5 cm depth (Wienhold and Halvorson, 1999). Greater nutrient transformation potential of the continuous crop, NT system was also reflected through microbial biomass levels, which were approximately two and half times greater in SW-WW-SF, NT as compared with SW-F, CT. Furthermore, the percentage of microbial biomass $\mathrm{C}$ as SOC averaged 4.3 for SW-WW-SF, NT and 2.6 for SW-F, CT $(P=0.0206)$.

Explanations for the differences in soil condition between SW-WW-SF, NT and SW-F, CT could partially be found through previous studies reporting biomass inputs into the soil. For example, Halvorson et al. (2002) found above-ground biomass production to be nearly two-fold greater in SW-WW-SF, NT (40.2 $\left.\mathrm{Mg} \mathrm{ha}^{-1}\right)$ as compared with SW-F, CT $\left(21.8 \mathrm{Mgha}^{-1}\right)$ during the first 12 years of the study. Likewise, NT was found to enhance total root length growth by $65 \%$ over that observed in CT from 1988 to 1990, thereby resulting in greater below-ground biomass input in NT (Merrill et al., 1996).

As a contrast to the cropped treatments, the grazed pasture possessed greater values for all measured soil properties at $0-7.5 \mathrm{~cm}$ as compared with SW-WW-SF, NT, except for infiltration rate. Higher soil water content at the time of measurement was responsible for the slower rate in the grazed pasture (data not shown). At the $15-30 \mathrm{~cm}$ depth, EC and soil $\mathrm{NO}_{3}-\mathrm{N}$ were lower in the grazed pasture relative to SW-WW-SF, NT, likely the result of greater retention of available nutrients, a common observation in grassland ecosystems (Wedin, 1999; Wienhold et al., 2001). 
Table 4

Mean values of soil properties affected by tillage in a long-term cropping systems experiment established in 1993 near Mandan, $\mathrm{ND}$

\begin{tabular}{|c|c|c|}
\hline & Minimum tillage & No-till \\
\hline \multicolumn{3}{|l|}{$0-7.5 \mathrm{~cm}^{\mathrm{a}}$} \\
\hline Soil bulk density $\left(\mathrm{Mg} \mathrm{m}^{-3}\right)$ & $1.26 \mathrm{a}^{\mathrm{b}}$ & $1.29 \mathrm{~b}$ \\
\hline $\mathrm{EC}\left(\mathrm{dS} \mathrm{m} \mathrm{m}^{-1}\right)^{\mathrm{c}}$ & 0.18 & 0.17 \\
\hline Soil pH $\left(-\log \left[\mathrm{H}^{+}\right]\right)$ & 5.87 & 5.89 \\
\hline Soil $\mathrm{NO}_{3}-\mathrm{N}\left(\mathrm{kg} \mathrm{ha}^{-1}\right)$ & 5.5 & 5.6 \\
\hline $\mathrm{SOC}\left(\mathrm{Mg} \mathrm{ha}^{-1}\right)$ & 20.36 & 19.79 \\
\hline $\mathrm{TN}\left(\mathrm{Mgha}^{-1}\right)$ & 2.17 & 2.14 \\
\hline \multicolumn{3}{|l|}{$\mathrm{POM}\left(\mathrm{Mg} \mathrm{ha}^{-1}\right)$} \\
\hline $0.053-0.5 \mathrm{~mm}$ & $5.85 \mathrm{a}$ & $5.44 \mathrm{~b}$ \\
\hline $0.5-2.0 \mathrm{~mm}$ & $1.39 \mathrm{a}$ & $1.18 \mathrm{~b}$ \\
\hline $0.053-2.0 \mathrm{~mm}$ & $7.24 \mathrm{a}$ & $6.62 \mathrm{~b}$ \\
\hline SOM $(\%)$ & $11.9 \mathrm{a}$ & $10.8 \mathrm{~b}$ \\
\hline PMN $\left(\mathrm{kg} \mathrm{ha}^{-1}\right)$ & $19.2 \mathrm{a}$ & $15.8 \mathrm{~b}$ \\
\hline Microbial biomass $\mathrm{C}\left(\mathrm{kg} \mathrm{ha}^{-1}\right)$ & 705 a & $620 \mathrm{~b}$ \\
\hline Microbial biomass $\mathrm{N}\left(\mathrm{kg} \mathrm{ha}^{-1}\right)$ & 43 & 39 \\
\hline \multicolumn{3}{|l|}{$7.5-15 \mathrm{~cm}$} \\
\hline Soil bulk density $\left(\mathrm{Mg} \mathrm{m}^{-3}\right)$ & $1.41 \mathrm{a}$ & $1.39 \mathrm{~b}$ \\
\hline
\end{tabular}

${ }^{\text {a }}$ All properties are presented for $0-7.5 \mathrm{~cm}$. Below $7.5 \mathrm{~cm}$, only properties affected by tillage are shown.

${ }^{b}$ Values within a row followed by a different letter are significantly different at $P<0.1$.

${ }^{\mathrm{c}} \mathrm{EC}$ : electrical conductivity; SOC: soil organic carbon; TN: total nitrogen; POM: particulate organic matter; PMN: potentially mineralizable $\mathrm{N}$.

\subsection{3 experiment}

\subsubsection{Effects of tillage}

In the 1993 experiment, tillage effects on soil quality indicators were limited to soil bulk density, POM, PMN, and microbial biomass C (Table 4). Trends in soil bulk density are generally considered a rough approximation of soil structural changes. In light of this, NT resulted in greater soil consolidation at $0-7.5$, while MT resulted in tillage-induced compaction at $7.5-15 \mathrm{~cm}$. Absolute differences in soil bulk density between treatments at both depths, however, were quite small $\left(0.02-0.03 \mathrm{Mg} \mathrm{m}^{-3}\right)$. None of the bulk densities measured were high enough to affect crop root growth. No significant differences were observed between tillage treatments among soil chemical properties, although soil $\mathrm{pH}$ values for both treatments fell within the moderately acid range (Table 4).
Table 5

Mean values of stover yield over 8 years as affected by tillage and crop sequence for a long-term cropping system experiment established in 1993 near Mandan, ND

\begin{tabular}{ll}
\hline Treatment & Crop residue $\left(\mathrm{Mg} \mathrm{ha}^{-1}\right)^{\mathrm{a}}$ \\
\hline Tillage & \\
$\quad$ Minimum tillage & 26.6 \\
No-tillage & 26.0 \\
LSD (0.1) & NS \\
Crop sequence & \\
CSW+ & \\
CSW- & 31.4 \\
SW-M & 29.3 \\
SW-S-F & 30.3 \\
SW-S-R & 19.9 \\
SW-F & 27.2 \\
LSD (0.1) & 19.6 \\
\end{tabular}

${ }^{\text {a }}$ Crop residue samples collected at harvest from two $0.5 \mathrm{~m}^{2}$ areas in each plot. Results presented on an oven-dry basis.

${ }^{\mathrm{b}} \mathrm{CSW}+$ : continuous spring wheat, residue retained; CSW-: continuous spring wheat, residue removed; SW-M: spring wheat-millet; SW-S-F: spring wheat-safflower-fallow; SW-S-R: spring wheat-safflower-rye; SW-F: spring wheat-fallow.

Particulate organic matter was greater under MT than NT (Table 4). This trend was consistent for both POM fractions $(0.053-0.5$ and $0.5-2.0 \mathrm{~mm})$ as well as the percentage of POM present as soil organic matter. This somewhat surprising result was apparently caused by greater production of crop residue in MT (Table 5). While NT systems under annual cropping typically enhance biomass production relative to other forms of tillage in semi-arid environments (Deibert et al., 1986; Campbell et al., 1997; Halvorson et al., 2002), the wetter than normal growing conditions since 1993 may have resulted in greater biomass production in systems where the soil was able to dry out and warm up earlier in the growing season. Such a microclimatic effect may have occurred in MT relative to NT, thereby resulting in a greater return of residue to soil in the form of stover and roots. The trend of higher SOC and TN in MT as compared to NT strengthened this possible explanation, along with the significantly higher levels of PMN and microbial biomass C in MT (Table 4).

\subsubsection{Effects of crop sequence}

Continuous cropping tended to enhance near-surface soil condition relative to crop sequences that included fallow (Table 6). Soil quality indicators affected by 
Table 6

Mean values of soil properties affected by crop sequence in a long-term cropping systems experiment established in 1993 near Mandan, ND

\begin{tabular}{|c|c|c|c|c|c|c|}
\hline Soil property & $\mathrm{CSW}+{ }^{\mathrm{a}}$ & CSW- & SW-M & SW-S-F & SW-S-R & SW-F \\
\hline \multicolumn{7}{|l|}{$0-7.5 \mathrm{~cm}^{\mathrm{b}}$} \\
\hline Soil bulk density $\left(\mathrm{Mg} \mathrm{m}^{-3}\right)$ & 1.26 & 1.31 & 1.26 & 1.27 & 1.26 & 1.28 \\
\hline $\mathrm{EC}\left(\mathrm{dS} \mathrm{m}^{-1}\right)^{\mathrm{c}}$ & 0.18 & 0.17 & 0.17 & 0.18 & 0.18 & 0.17 \\
\hline Soil pH $\left(-\log \left[\mathrm{H}^{+}\right]\right)$ & $5.77 c^{d}$ & $5.87 \mathrm{bc}$ & $5.77 \mathrm{c}$ & $5.95 \mathrm{~b}$ & $5.89 \mathrm{~b}$ & $6.05 \mathrm{a}$ \\
\hline Soil $\mathrm{NO}_{3}-\mathrm{N}\left(\mathrm{kg} \mathrm{ha}^{-1}\right)$ & 6.6 & 5.6 & 6.0 & 5.3 & 5.8 & 4.3 \\
\hline SOC $\left(\mathrm{Mg} \mathrm{ha}^{-1}\right)$ & 20.66 & 22.31 & 20.93 & 19.31 & 18.28 & 18.76 \\
\hline $\mathrm{TN}\left(\mathrm{Mg} \mathrm{ha}^{-1}\right)$ & 2.19 & 2.33 & 2.20 & 2.05 & 2.08 & 2.08 \\
\hline \multicolumn{7}{|l|}{ POM $\left(\mathrm{Mg} \mathrm{ha}^{-1}\right)$} \\
\hline $0.053-0.5 \mathrm{~mm}$ & $6.35 \mathrm{ab}$ & $6.68 \mathrm{a}$ & $5.92 \mathrm{bc}$ & $4.83 \mathrm{~d}$ & $5.34 \mathrm{~cd}$ & $4.76 \mathrm{~d}$ \\
\hline $0.5-2.0 \mathrm{~mm}$ & $1.98 \mathrm{a}$ & $1.27 \mathrm{~b}$ & $1.46 \mathrm{~b}$ & $0.93 \mathrm{c}$ & $1.16 \mathrm{bc}$ & $0.93 \mathrm{c}$ \\
\hline $0.053-2.0 \mathrm{~mm}$ & $8.33 \mathrm{a}$ & $7.95 \mathrm{ab}$ & $7.38 \mathrm{~b}$ & $5.76 \mathrm{c}$ & $6.50 \mathrm{c}$ & $5.69 \mathrm{c}$ \\
\hline SOM $(\%)$ & $13.3 \mathrm{a}$ & $12.0 \mathrm{~b}$ & $11.9 \mathrm{~b}$ & $9.7 \mathrm{c}$ & $11.1 \mathrm{~b}$ & $9.9 \mathrm{c}$ \\
\hline PMN $\left(\mathrm{kg} \mathrm{ha}^{-1}\right)$ & $16.0 \mathrm{~b}$ & $22.5 \mathrm{a}$ & $17.4 \mathrm{~b}$ & $14.8 \mathrm{~b}$ & $17.4 \mathrm{~b}$ & $17.0 \mathrm{~b}$ \\
\hline Microbial biomass $\mathrm{C}\left(\mathrm{kg} \mathrm{ha}^{-1}\right)$ & $673 \mathrm{ab}$ & 792 a & $695 \mathrm{ab}$ & $591 \mathrm{~b}$ & $663 \mathrm{ab}$ & $562 \mathrm{~b}$ \\
\hline Microbial biomass $\mathrm{N}\left(\mathrm{kg} \mathrm{ha}^{-1}\right)$ & 40 & 52 & 43 & 40 & 42 & 28 \\
\hline \multicolumn{7}{|l|}{$7.5-15 \mathrm{~cm}$} \\
\hline $\mathrm{EC}\left(\mathrm{dS} \mathrm{m}^{-1}\right)$ & $0.15 \mathrm{ab}$ & $0.16 \mathrm{a}$ & $0.14 \mathrm{~b}$ & $0.15 \mathrm{ab}$ & $0.14 \mathrm{~b}$ & $0.14 \mathrm{~b}$ \\
\hline
\end{tabular}

${ }^{\text {a }} \mathrm{CSW}+$ : continuous spring wheat, residue retained; CSW-: continuous spring wheat, residue removed; SW-M: spring wheat-millet; SW-S-F: spring wheat-safflower-fallow; SW-S-R: spring wheat-safflower-rye; SW-F: spring wheat-fallow.

${ }^{\mathrm{b}}$ All properties are presented for $0-7.5 \mathrm{~cm}$. Below $7.5 \mathrm{~cm}$, only properties affected by crop sequence are shown.

${ }^{\mathrm{c}}$ EC: electrical conductivity; SOC: soil organic carbon; TN: total nitrogen; POM: particulate organic matter; PMN: potentially mineralizable $\mathrm{N}$.

d Values within a row not followed by the same letter are significantly different at $P<0.1$.

crop sequence included soil $\mathrm{pH}, \mathrm{EC}, \mathrm{POM}, \mathrm{PMN}$, and microbial biomass $\mathrm{C}$. Crop sequence effects on soil $\mathrm{pH}$ were driven by the acidifying effect of $\mathrm{N}$ fertilization. The sequence receiving the least fertilizer $\mathrm{N}$ (SW-F) possessed the highest soil $\mathrm{pH}(6.05)$, while the sequences receiving the most fertilizer $\mathrm{N}$ and having the highest average stover production $(\mathrm{CSW}+$, SW-M) possessed the lowest soil pH (5.77). Soils throughout the northern Great Plains possess a buffer against acidification because they are often rich in $\mathrm{CaCO}_{3}$, resulting in soil $\mathrm{pH}$ levels near neutral or slightly alkaline in the surface horizons (Bowman and Halvorson, 1998). Given the trend in soil $\mathrm{pH}$ among crop sequences within the first 8 years of the experiment, however, it is apparent lime application will eventually be necessary on this soil for crops to reach their full physiological potential.

Particulate organic matter, the fraction of soil organic matter composed mainly of plant residue, was greatest in continuous spring wheat $(\mathrm{CSW}+$ and CSW-) and lowest in sequences with fallow (SW-S-F and SW-F) (Table 6). This general trend among crop sequences was similar for the $0.053-0.5 \mathrm{~mm}$ POM fraction, which made up an average of $82 \%$ of total POM. The larger POM fraction $(0.5-2.0 \mathrm{~mm})$, was significantly greater in $\mathrm{CSW}+$ as compared with the other sequences; likely a reflection of the effect of stover production and its retention on the soil surface for this less-degraded soil organic matter fraction. The percentage of POM present as soil organic matter was different among crop sequences with $\mathrm{CSW}+$ possessing the most (13.3\%), CSW-, SW-M, and SW-S-R intermediate (Average $=11.7 \%$ ), and SW-S-F and SW-F the least (Average $=9.8 \%$ ). Overall, continuous cropping and fallow effects on POM were similar to results from previous research in the central Great Plains (Bowman et al., 1999).

Potentially mineralizable $\mathrm{N}$ was greater in $\mathrm{CSW}-$ $22.5 \mathrm{~kg} \mathrm{ha}^{-1}$ than all other crop sequences (Average $=$ $16.5 \mathrm{~kg} \mathrm{ha}^{-1}$ ), indicating greater $\mathrm{N}$ mineralization potential over the growing season for that crop sequence (Table 6). The same sequence possessed significantly greater microbial biomass $\mathrm{C}\left(792 \mathrm{~kg} \mathrm{ha}^{-1}\right)$ as compared with sequences with fallow (SW-S-F and 
Table 7

Correlation coefficients for significant relationships $(P<0.1)$ among soil properties at $0-7.5 \mathrm{~cm}$ and stover yield for a long-term cropping systems experiment established in 1993 near Mandan, ND

\begin{tabular}{|c|c|c|c|c|c|c|c|c|c|c|}
\hline \multirow[t]{2}{*}{ Indicators } & \multirow[t]{2}{*}{ Stover } & \multirow[t]{2}{*}{$\mathrm{pH}$} & \multirow[t]{2}{*}{ SOC } & \multirow[t]{2}{*}{$\mathrm{TN}$} & \multicolumn{4}{|l|}{ POM } & \multirow[t]{2}{*}{ PMN } & \multirow[t]{2}{*}{$\mathrm{MBC}$} \\
\hline & & & & & $0.053-0.5 \mathrm{~mm}$ & $0.5-2.0 \mathrm{~mm}$ & $0.053-2.0 \mathrm{~mm}$ & $\operatorname{SOM}(\%)$ & & \\
\hline Stover & & $-0.67^{\mathrm{a}}$ & 0.45 & 0.51 & 0.71 & 0.61 & 0.74 & 0.70 & - & 0.37 \\
\hline $\mathrm{pH}^{\mathrm{b}}$ & & & -0.52 & -0.46 & -0.67 & -0.54 & -0.68 & -0.68 & - & -0.35 \\
\hline SOC & & & & 0.92 & 0.73 & 0.49 & 0.71 & 0.48 & 0.44 & 0.61 \\
\hline $\mathrm{TN}$ & & & & & 0.70 & 0.43 & 0.69 & 0.43 & 0.43 & 0.52 \\
\hline \multicolumn{11}{|l|}{ POM } \\
\hline $0.053-0.5 \mathrm{~mm}$ & & & & & & 0.63 & 0.96 & 0.86 & 0.50 & 0.61 \\
\hline $0.5-2.0 \mathrm{~mm}$ & & & & & & & 0.83 & 0.83 & - & 0.54 \\
\hline $0.053-2.0 \mathrm{~mm}$ & & & & & & & & 0.93 & 0.44 & 0.64 \\
\hline $\operatorname{SOM}(\%)$ & & & & & & & & & 0.31 & 0.56 \\
\hline PMN & & & & & & & & & & 0.58 \\
\hline
\end{tabular}

a All correlation coefficients are significant at $P<0.1$.

${ }^{\mathrm{b}} \mathrm{pH}$ : soil $\mathrm{pH}$; SOC: soil organic carbon; TN: total nitrogen; POM: particulate organic matter; SOM: soil organic matter; PMN: potentially mineralizable $\mathrm{N}$; MBC: microbial biomass $\mathrm{C}$.

SW-F; Average $=577 \mathrm{~kg} \mathrm{ha}^{-1}$ ). Microbial biomass is an important indicator of soil quality, functioning as an agent for the transformation and cycling of organic matter and plant nutrients. Furthermore, because of its responsiveness to management, microbial biomass can be a sensitive indicator of trends in soil organic matter levels (Gregorich et al., 1994).

Soil quality indicators were strongly influenced by the amount of residue returned to the soil in the 1993 experiment (Table 7). All soil properties at $0-7.5 \mathrm{~cm}$ were significantly associated with stover yield except for PMN $(P<0.1)$. The highest correlation with stover yield occurred for the total POM fraction ( $r=$ 0.74 ), underscoring its value as a sensitive indicator of residue incorporation into the intermediately labile soil organic matter fraction. Correlations between soil properties followed expected patterns given the strong positive relationships among soil organic matter-related characteristics (Gregorich et al., 1994). Soil $\mathrm{pH}$, however, was negatively associated with other soil properties, an expected result given the opposing effects of $\mathrm{N}$ fertilization on soil acidification and biomass production.

\section{Conclusions}

Contrasting management practices within the 1984 experiment resulted in distinctly different effects on soil condition for the $0-7.5 \mathrm{~cm}$ depth. Based on the status of the soil properties measured, the continuous crop, no-till management system had a positive effect on the capacity of the soil to function with respect to its ability to provide a source for plant nutrients, withstand erosion, and facilitate water transfer into the soil relative to the crop-fallow, conventional tillage system. Results from the 1993 experiment, however, were less definitive. Fewer soil properties were affected by management practices, with absolute differences for properties that were affected being generally quite small. In spite of this, trends in soil organic matter related properties indicated continuous cropping and minimum tillage were creating a more favorable plant growth environment relative to crop sequences with fallow or no-till. Taken together, results from both experiments confirm that farmers in the northern Great Plains of North America can improve soil quality by adopting production systems that employ intensive cropping practices with reduced tillage management.

\section{Acknowledgements}

We acknowledge the contribution of the Area IV Soil Conservation Districts in North Dakota for providing land and financial assistance to conduct the long-term cropping systems research reported in this manuscript. We thank Chuck Flakker, Jim Harms, 
Justin Hartel, Marv Hatzenbuhler, Curt Klein, Larry Renner, Delmer Schlenker, and Dawn Wetch for maintenance of research plots and Bruce Boehm, John Bullinger, and Faye Kroh for assistance with field sampling. Gary Brucker, Jamie Erhardt, Linda Jawson, Nate Shilman, Nick Shilman, Becky Wald, and Alexa Zink provided technical support during sample processing and laboratory analyses.

\section{References}

Aase, J.K., Pikul, J.L., 1995. Crop and soil response to long-term tillage practices in the northern Great Plains. Agron. J. 87, 652-656.

Arshad, M.A., Franzluebbers, A.J., Azooz, R.H., 1999. Components of surface soil structure under conventional and no-tillage in northwestern Canada. Soil Till. Res. 53, 41-47.

Blake, G.R., Hartge, K.H., 1986. Bulk density. In: Klute, A. (Ed.), Methods of Soil Analysis. Part 1. Physical and Mineralogical Methods, 2nd ed. SSSA Book Series No. 5. SSSA and ASA, Madison, WI, pp. 363-382.

Bowman, R.A., Halvorson, A.D., 1998. Soil chemical changes after nine years of differential $\mathrm{N}$ fertilization in a no-till dryland wheat-corn-fallow rotation. Soil Sci. 163, 241-247.

Bowman, R.A., Vigil, M.F., Nielsen, D.C., Anderson, R.L., 1999. Soil organic matter changes in intensively cropping dryland systems. Soil Sci. Soc. Am. J. 63, 186-191.

Bundy, L.G., Meisinger, J.J., 1994. Nitrogen availability indices. In: Weaver, R.W., Angle, S., Bottomley, P., Bezdicek, D., Smith, S., Tabatabai, A., Wollum, A. (Eds.), Methods of Soil Analysis. Part 2. Microbiological and Biochemical Methods. SSSA Book Series No. 5. SSSA and ASA, Madison, WI, pp. 951-984.

Cambardella, C.A., Gajda, A.M., Doran, J.W., Wienhold, B.J., Kettler, T.A., 2000. Estimation of particulate and total organic matter by weight loss-on-ignition. In: Lal, R., Kimble, J.M., Follett, R.F., Stewart, B.A. (Eds.), Assessment Methods for Soil Carbon. Lewis Publication, Boca Raton, FL, pp. 349-359.

Campbell, C.A., McConkey, B.G., Zenter, R.P., Selles, F., Curtin, D., 1996. Long-term effects of tillage and crop rotations on soil organic $\mathrm{C}$ and total $\mathrm{N}$ in a clay soil in southwestern Saskatchewan. Can. J. Soil Sci. 76, 395-401.

Campbell, C.A., McConkey, B.G., Biederbeck, V.O., Zenter, R.P., Tessier, S., Hahn, D.L., 1997. Tillage and fallow frequency effects on selected soil quality attributes in a coarse-textured Brown Chernozem. Can. J. Soil Sci. 77, 497-505.

Dahnke, W.C., Whitney, D.A., 1988. Measurement of soil salinity. In: Recommended Chemical Soil Test Procedures for the North Central Region. North Central Regional Publication 221. North Dakota Agric. Exp. Stn. Bull. 499, 32-34.

Deibert, E.J., French, E., Hoag, B., 1986. Water storage and use by spring wheat under conventional tillage and no-till in continuous and alternative crop-fallow systems in the northern Great Plains. J. Soil Water Conserv. 41, 53-58.
Dick, W.A., 1983. Organic carbon, nitrogen, and phosphorus concentrations and $\mathrm{pH}$ in soil profiles as affected by tillage intensity. Soil Sci. Soc. Am. J. 47, 102-107.

Doran, J.W., 1980. Soil microbial and biochemical changes associated with reduced tillage. Soil Sci. Soc. Am. J. 44, 765771.

Eckert, D.J., 1988. Recommended $\mathrm{pH}$ and lime requirement tests. In: Recommended Chemical Soil Test Procedures for the North Central Region. North Central Regional Publication 221. North Dakota Agric. Exp. Stn. Bull. 499, 6-8.

Follett, R.F., Peterson, G.A., 1988. Surface soil nutrient distribution as affected by wheat-fallow tillage systems. Soil Sci. Soc. Am. J. 52, 141-147.

Follett, R.F., Schimel, D.S., 1989. Effect of tillage practices on microbial biomass dynamics. Soil Sci. Soc. Am. J. 53, 10911096.

Franzluebbers, A.J., 2002. Soil organic matter stratification ratio as an indicator of soil quality. Soil Till. Res. 66, 95-106.

Franzluebbers, A.J., Haney, R.L., Hons, F.M., Zuberer, D.A., 1999. Assessing biological soil quality with chloroform fumigation-incubation: why subtract a control? Can. J. Soil Sci. 79, 521-528.

Gajda, A.M., Doran, J.W., Kettler, T.A., Wienhold, B.J., Pikul, J.L., Cambardella, C.A., 2000. Soil quality evaluations of alternative and conventional management systems in the Great Plains. In: Lal, R., Kimble, J.M., Follett, R.F., Stewart, B.A. (Eds.), Assessment Methods for Soil Carbon. Lewis Publication, Boca Raton, FL, pp. 381-400.

Gregorich, E.G., Ellert, B.H., 1993. Light fraction and macroorganic matter in mineral soils. In: Carter, M.R. (Ed.), Soil Sampling Methods and Analysis. Can. Soc. Soil Sci./Lewis Publication, Boca Raton, FL, pp. 397-407.

Gregorich, E.G., Carter, M.R., Angers, D.A., Monreal, C.M., Ellert, B.H., 1994. Towards a minimum data set to assess soil organic matter quality in agricultural soils. Can. J. Soil Sci. 74, 367385.

Halvorson, A.D., Wienhold, B.J., Black, A.L., 2002. Tillage, nitrogen, and cropping system effects on soil carbon sequestration. Soil Sci. Soc. Am. J. 66, 906-912.

Havlin, J.L., Kissel, D.E., Maddux, L.D., Claassen, M.M., Long, J.H., 1990. Crop rotation and tillage effects on soil organic carbon and nitrogen. Soil Sci. Soc. Am. J. 54, 448-452.

Islam, K.R., Weil, R.R., 1998. Microwave irradiation of soil for routine measurement of microbial biomass carbon. Biol. Fert. Soils 27, 408-416.

Kemper, W.D., Rosenau, R.C., 1986. Aggregate stability and size distribution. In: Klute, A. (Ed.), Methods of Soil Analysis. Part 1. Physical and Mineralogical Methods, 2nd ed. SSSA Book Series No. 5. SSSA and ASA, Madison, WI, pp. 425-442.

Littell, R.C., Milliken, G.A., Stroup, W.W., Wolfinger, R.D., 1996. SAS System for Mixed Models. SAS Institute Inc., Cary, NC.

Merrill, S.D., Black, A.L., Bauer, A., 1996. Conservation tillage affects root growth of dryland spring wheat under drought. Soil Sci. Soc. Am. J. 60, 575-583.

Merrill, S.D., Black, A.L., Fryrear, D.W., Saleh, A., Zobeck, T.M., Halvorson, A.D., Tanaka, D.L., 1999. Soil wind erosion hazard of spring wheat-fallow as affected by long-term climate and tillage. Soil Sci. Soc. Am. J. 63, 1768-1777. 
Mulvaney, R.L., 1996. Nitrogen-inorganic forms. In: Sparks, D.L. (Ed.), Methods of Soil Analysis. Part 3. Chemical Methods. SSSA Book Series No. 5. SSSA and ASA, Madison, WI, pp. 1123-1184.

Paul, E.A., Harris, D., Klug, M.J., Ruess, R.W., 1999. The determination of microbial biomass. In: Robertson, G.P., Coleman, D.C., Bledsoe, C.S., Sollins, P. (Eds.), Standard Soil Methods for Long-Term Ecological Research. Oxford University Press, New York, pp. 291-317.

Peterson, G.A., 1996. Cropping systems in the Great Plains. J. Prod. Agric. 9, 179.

Peterson, G.A., Schlegel, A.J., Tanaka, D.L., Jones, O.R., 1996. Precipitation use efficiency as affected by cropping and tillage systems. J. Prod. Agric. 9, 180-186.

Pikul, J.L., Aase, J.K., 1995. Infiltration and soil properties as affected by annual cropping in the northern Great Plains. Agron. J. 87, 656-662.

Salinas-Garcia, J.R., Hons, F.M., Matocha, J.E., Zuberer, D.A., 1997. Soil carbon and nitrogen dynamics as affected by long-term tillage and nitrogen fertilization. Biol. Fert. Soils 25, 182-188.

Sarrantonio, M., Doran, J.W., Liebig, M.A., Halvorson, J.J., 1996. On-farm assessment of soil quality and health. In: Doran, J.W., Jones, A.J. (Eds.), Methods for Assessing Soil Quality. Soil Sci. Soc. Am. Spec. Publ. 49. SSSA, Madison, WI, pp. 83-105.

SAS Institute, 1990. SAS/STAT User's Guide, Version 6.0, 4th ed., vol. 2. SAS Institute, Cary, NC.

Shen, S.M., Pruden, G., Jenkinson, D.S., 1984. Mineralization and immobilization of nitrogen in fumigated soil and the measurement of microbial biomass nitrogen. Soil Biol. Biochem. 16, 437-444.

Smith, J.L., Doran, J.W., 1996. Measurement and use of pH and electrical conductivity for soil quality analysis. In: Doran, J.W.,
Jones, A.J. (Eds.), Methods for Assessing Soil Quality. Soil Sci. Soc. Am. Spec. Publ. 49. SSSA, Madison, WI, pp. 169-185.

Staley, T.E., Edwards, W.M., Scott, C.L., Owens, L.B., 1988. Soil microbial biomass and organic component alterations in a no-tillage chronosequence. Soil Sci. Soc. Am. J. 52, 998-1005.

Statistics Canada, 1996. Census of Canada. Statistics Canada Advisory Services. Website-http://www.statcan.ca/ (verified 19 November 2003).

Tanaka, D.L., Anderson, R.L., 1997. Soil water storage and precipitation storage efficiency of conservation tillage systems. J. Soil Water Conserv. 52, 363-367.

Tracy, P.W., Westfall, D.G., Elliott, E.T., Peterson, G.A., Cole, C.V., 1990. Carbon, nitrogen, phosphorus, and sulfur mineralization in plow and no-till cultivation. Soil Sci. Soc. Am. J. 54, 457461.

US Census Bureau, 2000. Statistical abstract of the United States-2000. US Government Printing Office, Washington, DC. Website-http://www.census.gov/statab/www/ (verified 19 November 2003).

Wedin, D.A., 1999. Nitrogen availability, plant-soil feedbacks and grassland stability. In: Eldridge, D., Freudenberger, D. (Eds.), People and Rangelands Building the Future. Proceedings of the VI International Rangeland Congress, vol. 1. Townsville, Australia, 17-23 July 1999, pp. 193-197.

Wienhold, B.J., Halvorson, A.D., 1998. Cropping system influences on several soil quality attributes in the northern Great Plains. J. Soil Water Conserv. 53, 254-258.

Wienhold, B.J., Halvorson, A.D., 1999. Nitrogen mineralization responses to cropping, tillage, and nitrogen rate in the northern Great Plains. Soil Sci. Soc. Am. J. 63, 192-196.

Wienhold, B.J., Hendrickson, J.R., Karn, J.F., 2001. Pasture management influences on soil properties in the northern Great Plains. J. Soil Water Conserv. 56, 27-31. 